\title{
A Simple Method to Develop Seismic Microzonation Maps for Cities in Northern Haiti and Elsewhere
}

\author{
Michael E. Kalinski \\ Associate Professor, Dept. of Civil Engineering \\ University of Kentucky \\ michael.kalinski@uky.edu
}

\author{
Kit Miyamoto \\ President, Miyamoto International, Inc. \\ Sacramento, California 95691 \\ kmiyamoto@miyamotointernational.com
}

\author{
Amir S. J. Gilani, Ph.D., S.E. \\ Manager, Earthquake Engineering \\ Miyamoto International, Inc. \\ agilani@miyamotointernational.com
}

\begin{abstract}
Many developing nations are situated in zones of high seismicity where earthquakes can lead to widespread property loss and loss of life. Similar-sized earthquakes are not nearly as devastating in developed nations because of access to stateof-practice engineering methods. Earthquake engineering to reduce property loss and loss of life includes geotechnical engineering to predict likely amounts of ground shaking. Herein, a simple geotechnical approach was implemented in four cities in northern Haiti, including Port-de-Paix, Cap-Haitien, Fort Liberte, and Ouanaminthe based. The approach was based on the use of a simple geophysical technique and the application of International Building Code criteria to calculate design levels of ground shaking. The Spectral-Analysisof-Surface-Waves (SASW) method is a geophysical technique that was employed in the four test cities during a five-day test period utilizing three workers and a backpack full of equipment. As a result of this investigation, microzonation maps depicting design ground surface shaking parameters were rapidly and inexpensively developed, which can be used by structural engineers for guidance in designing earthquake-resistant structures. This method can be easily deployed in other developing nations to provide these populations with nearly the same level of knowledge and protection against earthquakes that is realized in developed nations.
\end{abstract}

Index Terms - Haiti, earthquake engineering, seismic hazard, microzonation mapping, geophysics

\section{INTRODUCTION}

The Caribbean island of Hispaniola includes the countries of Haiti on the west and the Dominican Republic on the east (Fig. 1). The island sits on the boundary of the Caribbean and North American tectonic plates (Fig. 2). The Caribbean Plate is moving eastward relative to the North American Plate at a rate of approximately $20 \mathrm{~mm} / \mathrm{yr} .{ }^{1}$ The Caribbean Plate subducts beneath the North American plate east of Hispaniola, where the plate boundary is marked by a subduction zone and a chain of volcanic islands. The northern border of the Caribbean Plate is delineated by two left-lateral transform fault zones coincident with the northern and southern borders of Haiti. These fault zones are designated as the Septentrional-Oriente and Enriquilllo- 
International Journal for Service Learning in Engineering,

Humanitarian Engineering and Social Entrepreneurship

Vol. 10, No. 2, pp. 1-17, Fall 2015

ISSN 1555-9033

Plantain Garden fault zones. Displacement rates along these two faults are approximately 12 $\mathrm{mm} / \mathrm{y}$ and $8 \mathrm{~mm} / \mathrm{year}$, respectively.

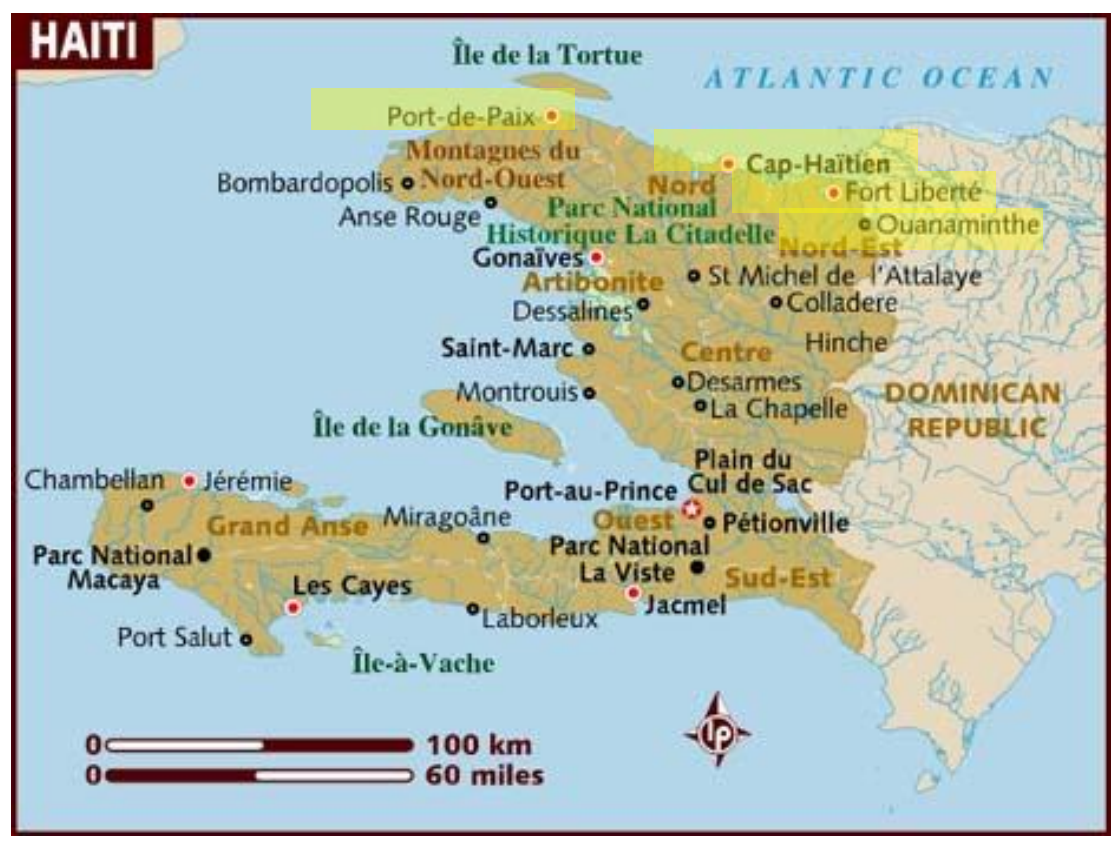

FIGURE 1

MAP OF HAITI HIGHLIGHTING PORT-DE-PAIX, CAP-HAITIEN, FORT LIBERTE, AND OUANAMINTHE.

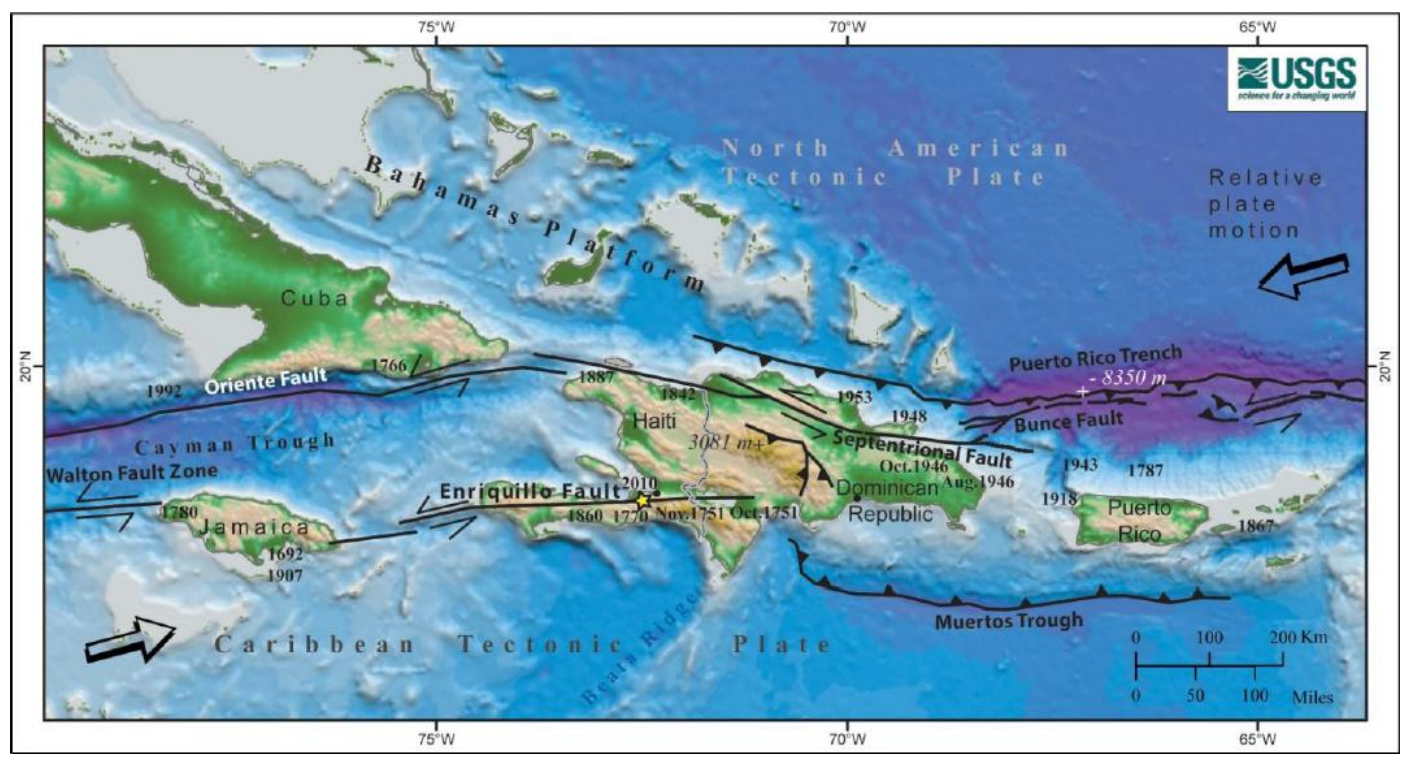

FIGURE 2

TECTONIC SETTING OF HAITI WITH 2010 PORT-AU-PRINCE EARTHQUAKE SHOWN AS YELLOW STAR $^{12}$ 
International Journal for Service Learning in Engineering, Humanitarian Engineering and Social Entrepreneurship Vol. 10, No. 2, pp. 1-17, Fall 2015

ISSN 1555-9033

Geology in northern Haiti is a mélange of upper Mesozoic and Cenozoic sedimentary rocks in the west with some igneous rocks in the east near Ouanaminthe. Geologic structure is highly faulted and complex due to the extensive tectonic activity. The rugged and unique topographic nature of Haiti is attributed to movement along these faults. In this regard, the tectonic setting of Haiti is similar to that of California where surface geology and seismicity are dominated by a large transform fault (the San Andreas Fault) that delineates the boundary between two tectonic plates. The presence of relatively young rocks also contributes to the high rate of attenuation of seismic waves within the country and attenuation rates in Haiti are similar to those found in California.

The M7.0 January 2010 Port-au-Prince Earthquake occurred as a result of movement along Enriquillo-Plantain Garden Fault Zone. This earthquake occurred on January 12 with an epicenter near the city of Leogane and a focal depth of approximately $13 \mathrm{~km}$ (Fig. 2). As a result of this earthquake, approximately 200,000 people were killed. Although this was a large earthquake, it had minimal impact on northern Haiti due to the relatively soft nature of the rocks and high attenuation rate.

The Septentrional-Oriente Fault Zone passes very close to the cities of Cap Haitien, Ft. Liberte, Port de Paix, and Ouanaminthe. This fault is considered to be a significant contributor to historical seismicity within the region, including the 1842 M8.1 Cap Haitien Earthquake (Fig. 2). The earthquake occurred on May 7 and led to approximately 5,000 deaths. Given the history of this fault and its tectonic setting, there is significant potential for future strong ground motion and widespread death and destruction, with an estimated recurrence interval of 1,000 years for M8.5 earthquakes. Given the potential for large earthquakes with M8.0 or greater, there is also a significant tsunami hazard, as was evident in 1842 when the Cap Haitien Earthquake was accompanied by a destructive tsunami.

A probabilistic seismic hazard assessment has been performed by the United States Geological Survey ${ }^{2,3}$ to predict levels of bedrock shaking corresponding to a $2 \%$ probability of exceedance within a 50-year exposure period (i.e. a return period of 2,475 years) in Haiti. Seismic hazard maps for Haiti are shown in Figs. 3 and 4 for 0.2-s bedrock spectral acceleration $\left(S_{s}\right)$ and 1.0-s bedrock spectral acceleration $\left(S_{1}\right)$. In order to predict ground surface shaking, bedrock shaking levels such as those depicted in Figs. 3 and 4 are combined with knowledge of the near-surface soil stiffness to perform a seismic site response analysis. As a result of a seismic site response analysis, ground surface spectral shaking levels are calculated. Bertil et al. ${ }^{4}$ recently reported results for such a study in Cap Haitien where soil stiffness was measured at various locations in the city and site response analyses were performed to generate a microzonation map of expected levels of shaking within the city. However, published maps and data for Port de Paix, Ft. Liberte, and Ouanaminthe are not available.

Herein, a study was performed to develop microzonation maps depicting design levels of ground shaking for the cities of Cap Haitien, Port de Paix, Ft. Liberte, and Ouanaminthe. Geophysical surface wave testing was performed to measure shear wave velocity profiles. For this study, shear wave velocity was determined using the Spectral-Analysis-of-Surface-Waves (SASW) method. This is an older alternative to newer surface wave methods such as the MASW, ReMi and H/V methods that is attractive in this case due to its speed and the need for minimal equipment on the ground. The SASW method was recently used in Leogane for a similar project. $^{5}$ For this study, sites were identified on aerial photos corresponding to open 
International Journal for Service Learning in Engineering,

Humanitarian Engineering and Social Entrepreneurship

Vol. 10, No. 2, pp. 1-17, Fall 2015

ISSN 1555-9033

areas at football fields, schools, parks, etc. Approximately 60 sites were selected, with more sites in the larger cities of Cap Haitien and Port de Paix.

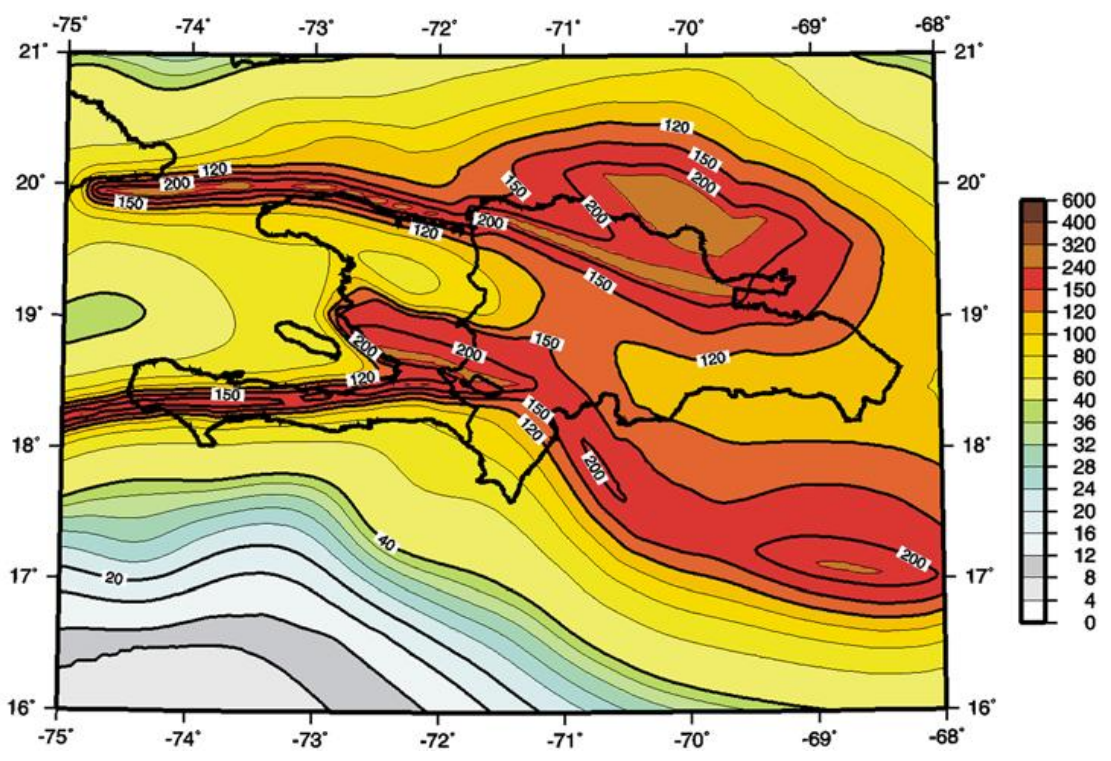

FIGURE 3

SEISMIC HAZARD MAP FOR HAITI DEPICTING SHORT-PERIOD SPECTRAL BEDROCK SHAKING $\left(S_{S}\right)$ CORRESPONDING TO A 2\% PROBABILITY OF EXCEEDANCE WITHIN A 50-YEAR EXPOSURE PERIOD (FRANKEL ET AL, 2010; FRANKEL ET AL., 2011).

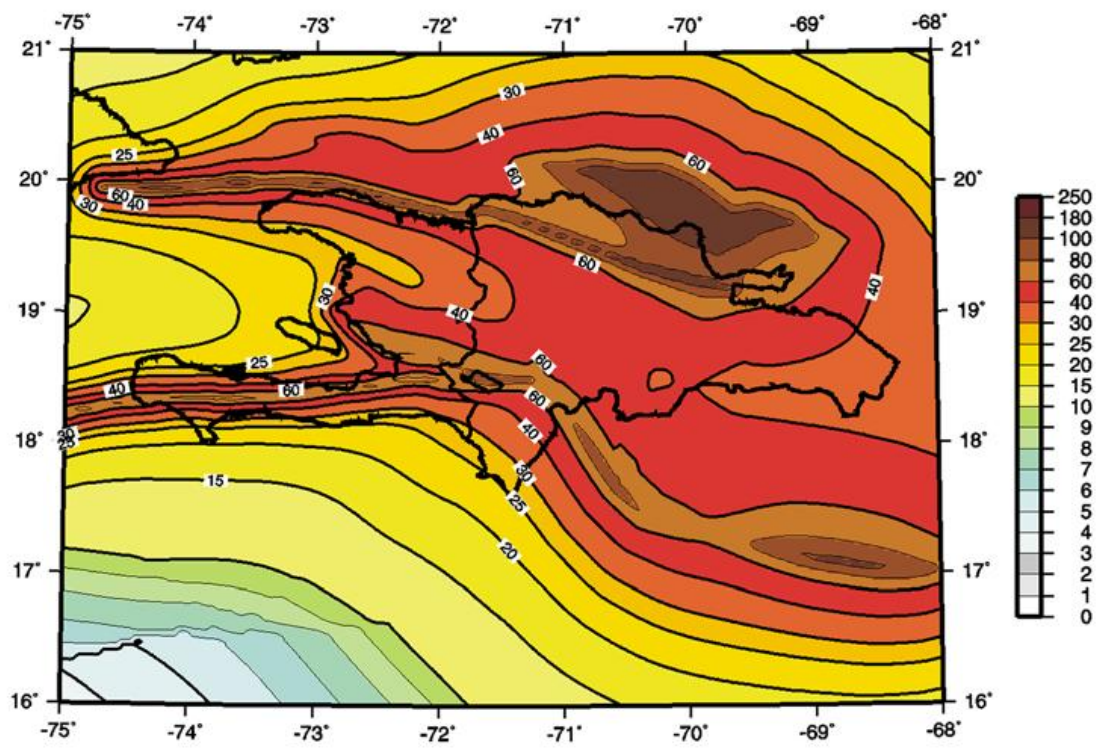

FIGURE 4

SEISMIC HAZARD MAP FOR HAITI DEPICTING LONG-PERIOD BEDROCK SHAKING $\left(S_{l}\right)$ CORRESPONDING TO A $2 \%$ PROBABILITY OF EXCEEDANCE WITHIN A 50-YEAR EXPOSURE PERIOD $^{2,3}$ 
Seismic site class is determined in terms of shear wave velocity, and is used to calculate ground surface design levels of ground shaking according to the International Building Code (IBC). Seismic site class is a relative description of the stiffness of the soil or rock column within $30 \mathrm{~m}(100 \mathrm{ft})$ of the ground surface. Seismic site class ranges from A to $\mathrm{F}$ as described in

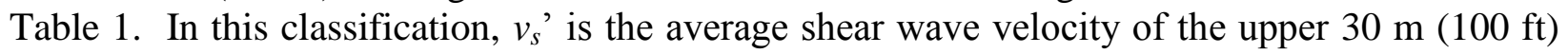
of the soil or rock column.

Previous research on seismicity in northern Haiti includes the United States Geological Survey (USGS) study to assess the probability of bedrock shaking across the island. In this study, maps depicting Maximum Considered Earthquake (MCE) spectral acceleration levels corresponding to 0.2 - and 1.0 -second periods $\left(S_{s}\right.$ and $\left.S_{l}\right)$ corresponding to a $2 \%$ probability of occurrence within a 50-year exposure period are presented (Figs. 3 and 4). These values represent expected levels of bedrock shaking and are used to calculate ground surface design ground acceleration in accordance with the International Building Code (IBC) as described in ASCE 7-10. ${ }^{6}$ To calculate ground shaking, the bedrock MCE spectral values are multiplied by acceleration and velocity coefficients $F_{a}$ and $F_{v}$ per ASCE 7-10 to account for the stiffness of the soil profile, and then further reduced by a factor of $2 / 3$ to convert MCE ground surface values to design ground surface spectral values $S_{D s}$ and $S_{D I}$.

TABLE 1

SEISMIC SITE CLASSIFICATION SYSTEM.

\begin{tabular}{cc}
\hline Site Class & Average shear wave velocity, $v_{s}{ }^{\prime}(\mathrm{m} / \mathrm{s})$ \\
\hline A & $>1,520$ \\
B & $760-1,520$ \\
C & $360-760$ \\
D & $180-360$ \\
E & $<180$ \\
F & soils deemed to be liquefiable \\
\hline
\end{tabular}

\section{Testing Program And Methods}

Geophysical testing was performed on December 9-13 in Cap Haitien, Port de Paix, Ft. Liberte, and Ouanaminthe (Fig. 1). A total of 65 test locations were initially identified. These locations were selected prior to testing. Locations corresponding to schools, churches, parks, and sports fields were selected due to the need for large, open spaces for testing. Private sites were avoided to minimize conflict with respect to access, and sites were selected to represent a cross-section of different soil types and soil stiffness. Of these 65 test points, testing was successfully completed at 56 sites as indicated in Table 2. Obstacles to successful data acquisition included inaccessible sites, denial of permission to test, and occasional instances of poor data quality due to noisy conditions. Coordinate information was obtained by GPS for test points were geophysical data were successfully acquired.

The Spectral-Analysis-of-Surface-Waves (SASW) method was used to perform geophysical seismic surface wave testing. The SASW method is a simple method to develop soundings of shear wave velocity versus depth for seismic site response analysis. ${ }^{7}$ The SASW method involves the use of an impulsive seismic energy source (typically a sledge hammer) and a pair of 
receivers (either geophones or accelerometers) spaced an equal distance apart in a straight line as shown in Fig. 5. When the ground is impacted, surface waves are generated. As they pass the two receivers, the energy recorded at each receiver is analyzed for spectral content. Differences in phase between the two receivers are calculated at each frequency, and this information is used to calculate variations in surface wave velocity with wavelength in the form of a dispersion curve. Since shorter-wavelength velocities only depend on shallow material and longerwavelength velocities depend upon deeper material, variations in velocity with wavelength are indicative of variations in shear wave velocity $\left(v_{s}\right)$ with depth. Through the process of forward modeling or numerical inversion, the $v_{s}$ profile ( $v_{s}$ as a function of depth) is derived. The $v_{s}$ profile is required for calculating seismic site response and quantifying ground surface acceleration for seismic design.

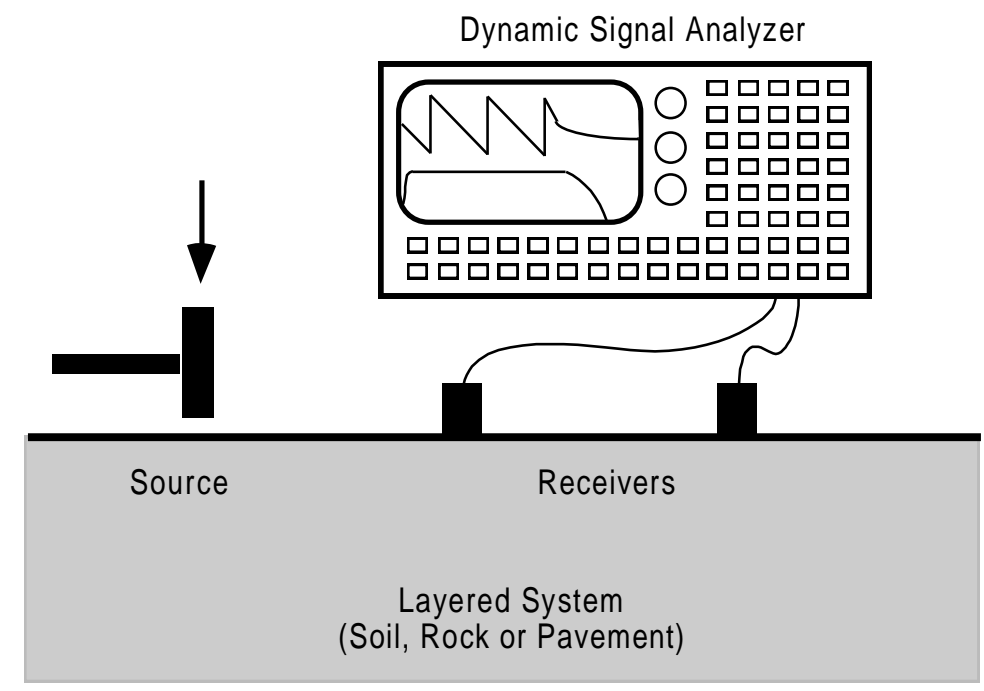

FIGURE 5

SCHEMATIC ILLUSTRATION OF THE SASW METHOD TEST CONFIGURATION.

The SASW method is a non-intrusive surface geophysical method. This eliminates the need for boreholes, which greatly facilitates acquisition of shear wave velocity data. The SASW method is a proven method that has been used successfully worldwide since the 1980s. It predates newer surface wave methods such as the Multichannel-Analysis-of-Surface Waves (MASW) method $^{8}$ and the Refraction Microtremor (ReMi) method ${ }^{9}$, but requires less field equipment. This advantage reduces cost and facilitates data acquisition in circumstances such as those found in Haiti where field activities involving the use of large amounts of expensive field equipment can draw negative attention from the public.

SASW testing was acquired using a geophone array with a $12.2-\mathrm{m}(40.0-\mathrm{ft})$ spacing with a Data Physics Quattro dynamic signal analyzer (Fig. 6). Surface wave dispersion curves were derived and inverted using the WinSASW forward modeling software package developed at the University of Texas. ${ }^{10}$ Seismic site class was determined according to ASCE 7-10. Short- and long-period MCE spectral acceleration were determined based on GPS location using the USGS database. Using this information, ground surface design spectral acceleration values were determined. These parameters are also included in Table 2. 


\section{RESULTS}

Typical examples of field data acquired in northern Haiti are depicted in Fig. 7. The resulting values for $v_{s}$ ' determined from analysis of the field surface wave data were converted into seismic site class and contoured for each of the four cities as depicted in Figs. 8-11. For Cap Haitien (Fig. 8), site classes from B to D were measured. Site Class B was found in higher elevations northwest of the city, while site class $\mathrm{C}$ was found at lower elevations and to the east of town. Site Class D was the softest classification found in Cap Haitien, and was found in the lowest lying area along the river. The shape of the site class map for Cap Haitien is consistent with results reported by Bertil et al. ${ }^{4}$ but the shear wave velocities reported herein are higher than those reported by Bertil et al. In the Bertil et al. ${ }^{4}$ research, site class $\mathrm{E}$ was reported for most of the lower-lying areas of Cap Haitien. Site class E is generally associated with deep deposits of soft soil. However, this section of Cap Haitien contains rock outcrops such as the outcrop a few hundred yards northwest of the airport terminal, which suggests that bedrock is relatively shallow. Seismic site class E is relatively uncommon and is generally restricted to areas with rapid deposition such as the deltas and estuaries of larger rivers. In the microzonation study performed by Cox et al. ${ }^{11}$ for Port au Prince, there were no site class E locations identified, and the softest site class identified was site class D. Bertil et al. ${ }^{4}$ based their site classifications for Cap Haitien in part on low observed SPT blow counts, but the correlation between blow count and shear wave velocity contains a large amount of statistical variability, so it is reasonable that sites with blow counts low enough to be classified as site class E could be classified as site class $\mathrm{D}$ based on shear wave velocity. Herein, the low-lying areas of Cap Haitien are classified as site class D based on seismic velocity, but may be classified as site class E or F if large amounts of soft clay are present or if soils are found to be liquefiable. In such cases, design levels of ground surface shaking may be higher than those presented herein.
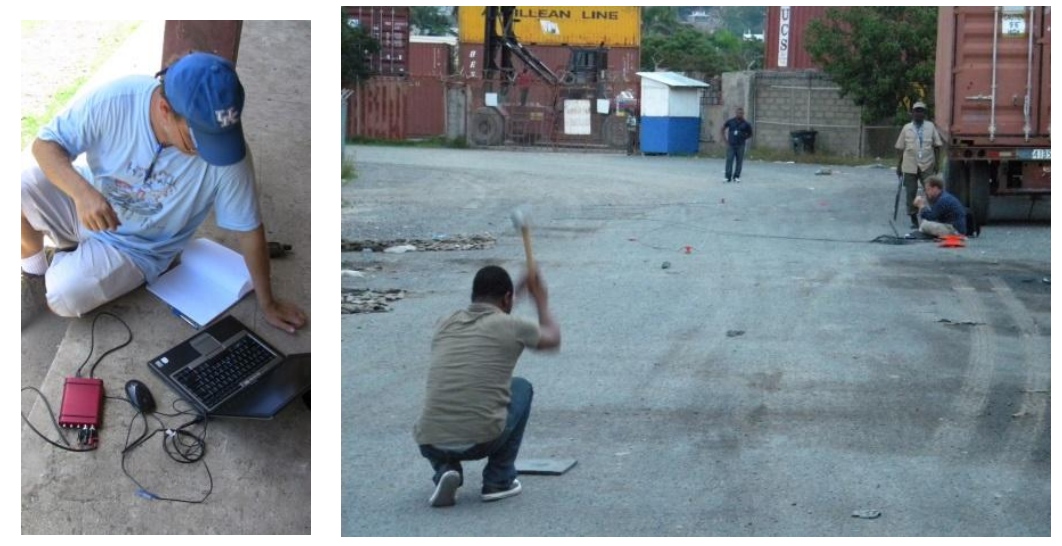

FIGURE 6

SASW DATA ACQUISITON IN HAITI.

For the other three sites (Port de Paix, Ft. Liberte, and Ouanaminthe), site class maps are presented in Figs. 9-11. These figures reveal that site classes from B to D were measured. Port de Paix and Ft. Liberte contained soils as soft as site class D, but also contained stiffer zones of 
site class B accompanied by rock outcrops such as the northernmost point at Ft. Liberte and Reservoir de Casernes in Port de Paix. Site class in Ouanaminthe was consistently stiff (B or C) throughout the city because of its inland location which is typically accompanied by a lack of soft soil deposits.

Short-period and long-period ground surface design spectral acceleration values $S_{D S}$ and $S_{D I}$ were calculated using the site class and MCE bedrock shaking levels presented in Table 2. The resulting values are also included in Table 2 and presented in the contour maps depicted in Figs. 12-18. A map of $S_{D S}$ for Ft. Liberte is not included herein because calculated values for $S_{D S}$ were $0.97 \mathrm{~g}$ throughout the city. For the other three cities, values of $S_{D S}$ mirrored values of shortperiod MCE bedrock spectral acceleration $\left(S_{S}\right)$ reported by the USGS, which indicates that soil conditions have a minimal effect on short-period (0.2-s) spectral acceleration at the ground surface. Values of $S_{D 1}$, on the other hand, mirrored the site class maps depicted in Figs. 8-11, which indicates that soil conditions play a more important role in predicting long-period (1.0-s) spectral acceleration at the ground surface.
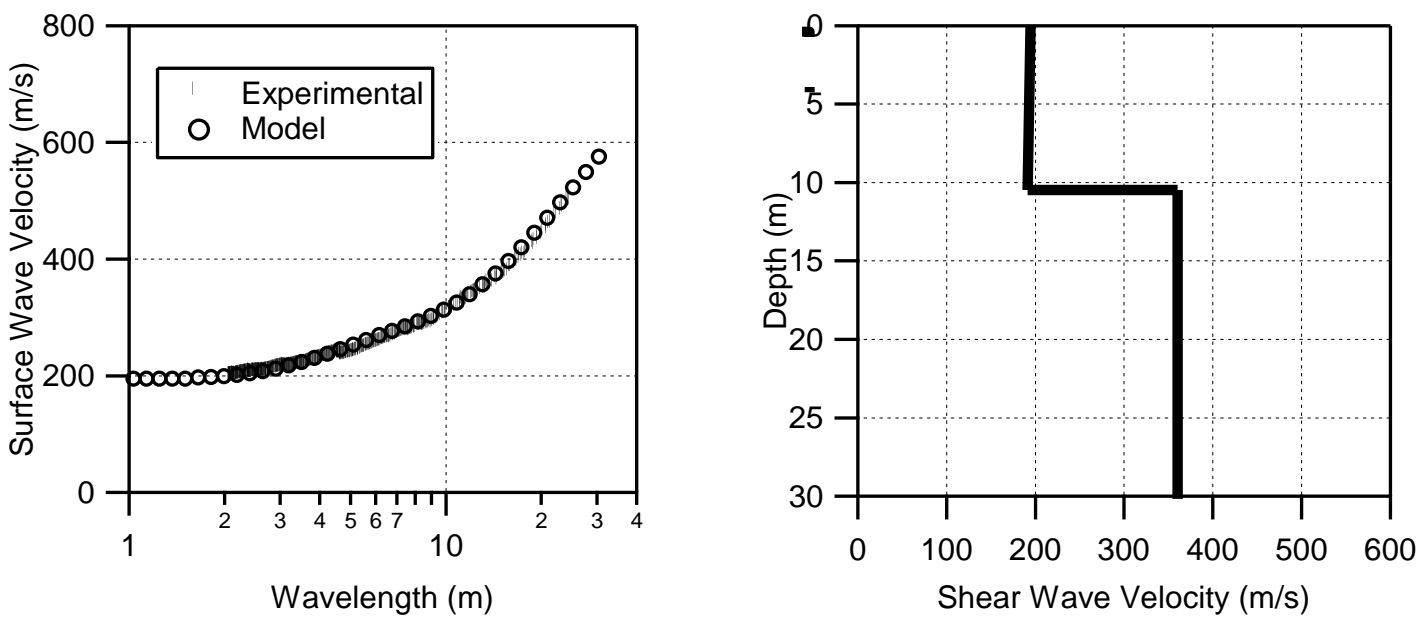

FIGURE 7

TYPICAL SASW DATA (ACQUIRED AT THE PORT-DE-PAIX AIRPORT).

\section{CONCLUSIONS}

Herein, results of a five-day field study to estimate the stiffness of near-surface soil and rock and develop microzonation maps of ground shaking at four earthquake-prone cities in northern Haiti are presented. The resulting microzonation maps of seismic site class and spectral ground surface acceleration will be useful to structural engineers to design structures that are relatively resistant to earthquakes using state-of-practice IBC methods. These maps are not as detailed as the microzonation maps typically generated in developed countries. In these instances, larger databases of available geophysical data are incorporated with geotechnical soil boring information and geological maps, and these databases can easily be supplemented by acquiring new data as needed. In developing nations, access to data, expertise, and funds to acquire the data and develop microzonation maps are limited. Nevertheless, the approach presented herein allows for the generation of maps that can be used to reduce property loss and loss of life. More 
importantly, the simplified field approach and mapping approach allow data to be acquired in a very short period of time and mapping to be performed with minimal cost and effort.

In developing nations that are prone to earthquakes, the approach presented herein is attainable. These methods can be used to create seismic micronozation maps in developing economies around the world. The microzonation maps can then be used to develop seismic hazard maps in those developing nations that do not have the economic capacity to use more expensive methods. For example, this technology can be used in the planning of supply chain corridors in developing nations. By using these methods, long term safety goals can be achieved in the investment of infrastructure that would have otherwise been unattainable due to cost or lack of accessibility to more expensive methods. Also, the development of social infrastructure can be enhanced with this technology, because this technology will allow soil behavior to be predicted, which in turn will allow for the design of safer and more resilient infrastructure with respect to earthquake hazards.

The equipment and methods presented herein have already been transferred to Haiti Engineering, a humanitarian engineering group in Haiti, so that they can perform testing and develop design ground shaking parameters themselves. ${ }^{5}$ The project that led to the donation of equipment to Haiti Engineering was sponsored by Geoscientists without Borders and also included the development of a step-by-step user's manual. This manual is available by request from the Author. This manual, along with about $\$ 8,000$ of equipment, will provide new users in developing nations with an "out-of-the-box" solution that they can use to perform testing and develop their own microzonation maps anywhere in the world. This will ultimately help geoscientists and governments in these nations to reduce property loss and loss of life due to earthquakes. By using this tool in the planning of all infrastructure that is prone to seismic hazards, the protection of life, property and the environment will be enhanced. The overall impact is infrastructure that is resilient and sustainable.

\section{ACKNOWLEDGMENTS}

The authors would like to thank the United Nations Development Programme in Haiti for their funding of this project.

\section{REFERENCES}

${ }^{1}$ ten Brink, U. S., Bakun, W. H., and Flores, Ca. H., 2011, "Historical Perspective on Seismic Hazard to Hispaniola and the Northeast Caribbean Region", Journal of Geophysical Research, Vol. 11, B12318.

${ }^{2}$ Frankel, A., Harmsen, S., Mueller, C., Calais, E., and Haase, J., 2010, “Documentation for Initial Seismic Hazard Maps for Haiti," Open File Report 2010-1067, United States Geological Survey.

3 Frankel, A., Harmsen, S., Mueller, C., Calais, E., and Haase, J., 2011, “Seismic Hazard Maps for Haiti," Earthquake Spectra, Vol. 27, No. S1, pp. S23-S41.

${ }^{4}$ Bertil., D., Rouille, A., Noury, G., Prepetit, C., Gilles, R., Sylvain, R., and Jean-Philippe, J., 2014, “An IBC Approach for Seismic Microzoning at Cap-Haitien (Haiti)," Proceedings of the Second European Conference on Earthquake Engineering and Seismology, Istanbul, Turkey, 25-29 August 2014. 
${ }^{5}$ Kalinski, M. E., Jean-Louis, M. and Lissade, H., 2014, "Transferring Technology for Surface Wave Testing and Seismic Site Response Analysis in Haiti," The Leading Edge, Vol. 33, No. 12, pp. 936-940.

${ }^{6}$ ASCE, 2010, Minimum Design Loads for Buildings and Other Structures: ASCE 7-10, American Society of Civil Engineers.

7 Stokoe II, K. H., Wright, S.G., Bay, J.A., and Roesset, J.M., 1994, Characterization of geotechnical sites by SASW Method: 12th International Conference of Soil Mechanics and Foundation Engineering, Proceedings.

8 Park, C. B., Miller, R. D., and Xia, J., 1999, Multichannel Analysis of Surface Waves: Geophysics, Vol. 64, pp. 800-808.

9 Louie, J. N., 2001, Faster, Better: Shear-Wave Velocity to 100 Meters Depth from Refraction Microtremor Arrays: Bulletin of the Seismological Society of America, Vol. 91 pp. 347-364.

${ }^{10}$ Joh, S. H., 1996, Advances in Interpretation and Analysis Techniques for Spectral-Analysis-ofSurface-Waves (SASW) Measurements: Ph.D. Dissertation, University of Texas at Austin.

${ }^{11}$ Cox, B. R., Bachhuber, J., Rathje, E., Wood., C. M., Dulberg, R., Kottke, A., Green, R. A., and Olson, S. M., 2011, "Shear Wave Velocity- and Geology-Based Seismic Microzonation of Port-au-Prince, Haiti," Earthquake Spectra, Vol. 27, No. S1, pp. S67-S92.

${ }^{12}$ USGS, 2015, Woods Hole Coastal and Marine Science Center Caribbean Tsunami and Earthquake Hazards Studies, http://woodshole.er.usgs.gov/project-pages/caribbean/atlantic+trench_large.html (last accessed April 28, 2015). 
International Journal for Service Learning in Engineering, Humanitarian Engineering and Social Entrepreneurship Vol. 10, No. 2, pp. 1-17, Fall 2015

ISSN 1555-9033

TABLE 2

SUMMARY OF TEST POINT LOCATIONS IN NORTHERN HAITI.

\begin{tabular}{|c|c|c|c|c|c|c|c|c|c|c|}
\hline Site ID & Latitude & Longitude & $\begin{array}{c}v_{s^{\prime}} \\
(\mathrm{m} / \mathrm{s})\end{array}$ & $\begin{array}{c}\text { Site } \\
\text { Class }\end{array}$ & $\begin{array}{c}S_{s} \\
(\mathrm{~g})\end{array}$ & $\begin{array}{l}S_{l} \\
(\mathrm{~g})\end{array}$ & $F a$ & $F v$ & $\begin{array}{c}S_{D S} \\
(\mathrm{~g})\end{array}$ & $\begin{array}{l}S_{D I} \\
(\mathrm{~g})\end{array}$ \\
\hline \multicolumn{11}{|l|}{ Cap Haitien } \\
\hline $\mathrm{C} 01$ & 19.753762 & -72.207450 & 770 & B & 1.50 & 0.57 & 1.0 & 1.0 & 1.00 & 0.38 \\
\hline $\mathrm{C} 02$ & 19.737858 & -72.194113 & 383 & $\mathrm{C}$ & 1.45 & 0.55 & 1.0 & 1.3 & 0.97 & 0.48 \\
\hline $\mathrm{C} 03$ & 19.714242 & -72.209328 & 198 & D & 1.34 & 0.49 & 1.0 & 1.5 & 0.89 & 0.49 \\
\hline $\mathrm{C} 04$ & 19.729441 & -72.210463 & 331 & $\mathrm{D}$ & 1.40 & 0.52 & 1.0 & 1.5 & 0.93 & 0.52 \\
\hline $\mathrm{C} 05$ & 19.758868 & -72.196838 & 541 & $\mathrm{C}$ & 1.51 & 0.58 & 1.0 & 1.3 & 1.01 & 0.50 \\
\hline $\mathrm{C} 06$ & 19.767367 & -72.196690 & 858 & B & 1.52 & 0.58 & 1.0 & 1.0 & 1.01 & 0.39 \\
\hline $\mathrm{C} 07$ & 19.723065 & -72.229828 & 904 & B & 1.37 & 0.50 & 1.0 & 1.0 & 0.91 & 0.33 \\
\hline $\mathrm{C} 08$ & 19.759133 & -72.205424 & 634 & $\mathrm{C}$ & 1.51 & 0.57 & 1.0 & 1.3 & 1.01 & 0.49 \\
\hline $\mathrm{C} 10$ & 19.766365 & -72.195438 & 556 & $\mathrm{C}$ & 1.52 & 0.58 & 1.0 & 1.3 & 1.01 & 0.50 \\
\hline $\mathrm{C} 12$ & 19.720426 & -72.182373 & 723 & $\mathrm{C}$ & 1.38 & 0.52 & 1.0 & 1.3 & 0.92 & 0.45 \\
\hline $\mathrm{C} 13$ & 19.736098 & -72.183616 & 335 & D & 1.44 & 0.55 & 1.0 & 1.5 & 0.96 & 0.55 \\
\hline C16 & 19.744899 & -72.207031 & 583 & C & 1.48 & 0.56 & 1.0 & 1.3 & 0.99 & 0.49 \\
\hline $\mathrm{C} 17$ & 19.745180 & -72.211137 & 431 & $\mathrm{C}$ & 1.48 & 0.56 & 1.0 & 1.3 & 0.99 & 0.49 \\
\hline C19 & 19.737479 & -72.201621 & 255 & D & 1.44 & 0.54 & 1.0 & 1.5 & 0.96 & 0.54 \\
\hline $\mathrm{C} 20$ & 19.741833 & -72.218249 & 731 & $\mathrm{C}$ & 1.46 & 0.55 & 1.0 & 1.3 & 0.97 & 0.48 \\
\hline $\mathrm{C} 21$ & 19.729250 & -72.200812 & 307 & D & 1.41 & 0.53 & 1.0 & 1.5 & 0.94 & 0.53 \\
\hline $\mathrm{C} 22$ & 19.740629 & -72.191711 & 606 & $\mathrm{C}$ & 1.46 & 0.56 & 1.0 & 1.3 & 0.97 & 0.49 \\
\hline $\mathrm{C} 23$ & 19.759772 & -72.196425 & 463 & $\mathrm{C}$ & 1.46 & 0.54 & 1.0 & 1.3 & 0.97 & 0.47 \\
\hline $\mathrm{C} 24$ & 19.760262 & -72.195888 & 244 & D & 1.50 & 0.57 & 1.0 & 1.5 & 1.00 & 0.57 \\
\hline $\mathrm{C} 25$ & 19.723668 & -72.248745 & 274 & D & 1.36 & 0.50 & 1.0 & 1.5 & 0.91 & 0.50 \\
\hline $\mathrm{C} 26$ & 19.729596 & -72.217162 & 291 & D & 1.41 & 0.52 & 1.0 & 1.5 & 0.94 & 0.52 \\
\hline \multicolumn{11}{|l|}{ Ft. Liberte } \\
\hline L01 & 19.674066 & -71.842198 & 366 & C & 1.46 & 0.56 & 1.00 & 1.30 & 0.97 & 0.49 \\
\hline L02 & 19.672548 & -71.841815 & 395 & $\mathrm{C}$ & 1.46 & 0.56 & 1.00 & 1.30 & 0.97 & 0.49 \\
\hline L03 & 19.669279 & -71.840001 & 457 & $\mathrm{C}$ & 1.46 & 0.56 & 1.00 & 1.30 & 0.97 & 0.49 \\
\hline L04 & 19.666986 & -71.840041 & 367 & $\mathrm{C}$ & 1.45 & 0.55 & 1.00 & 1.30 & 0.97 & 0.48 \\
\hline L05 & 19.661342 & -71.833347 & 282 & D & 1.45 & 0.55 & 1.00 & 1.50 & 0.97 & 0.55 \\
\hline L06 & 19.662107 & -71.831415 & 556 & $\mathrm{C}$ & 1.45 & 0.55 & 1.00 & 1.30 & 0.97 & 0.48 \\
\hline L07 & 19.655696 & -71.825740 & 442 & $\mathrm{C}$ & 1.45 & 0.54 & 1.00 & 1.30 & 0.97 & 0.47 \\
\hline \multicolumn{11}{|l|}{ Ouanaminthe } \\
\hline $\mathrm{O} 01$ & 19.5487129 & -71.7132756 & 601 & C & 1.20 & 0.46 & 1.00 & 1.34 & 0.80 & 0.41 \\
\hline $\mathrm{O} 02$ & 19.5440920 & -71.7127575 & 383 & $\mathrm{C}$ & 1.19 & 0.45 & 1.00 & 1.35 & 0.79 & 0.41 \\
\hline $\mathrm{O} 03$ & 19.5512718 & -71.7165773 & 940 & B & 1.20 & 0.46 & 1.00 & 1.00 & 0.80 & 0.31 \\
\hline O04 & 19.5489517 & -71.7189785 & 898 & B & 1.19 & 0.45 & 1.00 & 1.00 & 0.79 & 0.30 \\
\hline O05 & 19.5550289 & -71.7191787 & 392 & $\mathrm{C}$ & 1.21 & 0.46 & 1.00 & 1.34 & 0.81 & 0.41 \\
\hline O06 & 19.5584313 & -71.7236396 & 701 & $\mathrm{C}$ & 1.21 & 0.46 & 1.00 & 1.34 & 0.81 & 0.41 \\
\hline O07 & 19.5505189 & -71.7247734 & 460 & $\mathrm{C}$ & 1.19 & 0.45 & 1.00 & 1.35 & 0.79 & 0.41 \\
\hline $\mathrm{O} 08$ & 19.5547099 & -71.7257932 & 730 & C & 1.20 & 0.46 & 1.00 & 1.34 & 0.80 & 0.41 \\
\hline O09 & 19.5403305 & -71.7281898 & 470 & $\mathrm{C}$ & 1.17 & 0.45 & 1.00 & 1.35 & 0.78 & 0.41 \\
\hline $\mathrm{O} 10$ & 19.5340465 & -71.7290110 & 770 & B & 1.16 & 0.44 & 1.00 & 1.00 & 0.77 & 0.29 \\
\hline $\mathrm{O} 12$ & 19.5526106 & -71.7328483 & 770 & B & 1.19 & 0.46 & 1.00 & 1.00 & 0.79 & 0.31 \\
\hline $\mathrm{O} 13$ & 19.5577058 & -71.7322436 & 524 & C & 1.21 & 0.46 & 1.00 & 1.34 & 0.81 & 0.41 \\
\hline \multicolumn{11}{|l|}{ Port-de-Paix } \\
\hline P01 & 19.932000 & -72.851000 & 485 & $\mathrm{C}$ & 1.50 & 0.58 & 1.0 & 1.3 & 1.00 & 0.50 \\
\hline P02 & 19.936413 & -72.844886 & 725 & $\mathrm{C}$ & 1.51 & 0.59 & 1.0 & 1.3 & 1.01 & 0.51 \\
\hline P04 & 19.934311 & -72.847574 & 277 & D & 1.50 & 0.59 & 1.0 & 1.5 & 1.00 & 0.59 \\
\hline P05 & 19.937882 & -72.842815 & 274 & D & 1.51 & 0.59 & 1.0 & 1.5 & 1.01 & 0.59 \\
\hline P06 & 19.942592 & -72.852127 & 297 & D & 1.50 & 0.59 & 1.0 & 1.5 & 1.00 & 0.59 \\
\hline P07 & 19.940641 & -72.836378 & 1060 & B & 1.53 & 0.59 & 1.0 & 1.0 & 1.02 & 0.39 \\
\hline P09 & 19.939443 & -72.838707 & 386 & $\mathrm{C}$ & 1.52 & 0.59 & 1.0 & 1.3 & 1.01 & 0.51 \\
\hline P10 & 19.942569 & -72.848107 & 464 & $\mathrm{C}$ & 1.50 & 0.59 & 1.0 & 1.3 & 1.00 & 0.51 \\
\hline P11 & 19.949795 & -72.814795 & 444 & C & 1.60 & 0.60 & 1.0 & 1.3 & 1.07 & 0.52 \\
\hline P12 & 19.945507 & -72.808378 & 329 & D & 1.61 & 0.60 & 1.0 & 1.5 & 1.07 & 0.60 \\
\hline P13 & 19.952089 & -72.817248 & 513 & $\mathrm{C}$ & 1.59 & 0.60 & 1.0 & 1.3 & 1.06 & 0.52 \\
\hline P14 & 19.949390 & -72.821581 & 912 & B & 1.58 & 0.60 & 1.0 & 1.0 & 1.05 & 0.40 \\
\hline P15 & 19.944387 & -72.826410 & 1103 & B & 1.56 & 0.60 & 1.0 & 1.0 & 1.04 & 0.40 \\
\hline P16 & 19.937098 & -72.829479 & 327 & D & 1.54 & 0.59 & 1.0 & 1.5 & 1.03 & 0.59 \\
\hline P18 & 19.948435 & -72.797556 & 359 & D & 1.64 & 0.60 & 1.0 & 1.5 & 1.09 & 0.60 \\
\hline
\end{tabular}


International Journal for Service Learning in Engineering, Humanitarian Engineering and Social Entrepreneurship Vol. 10, No. 2, pp. 1-17, Fall 2015

ISSN 1555-9033

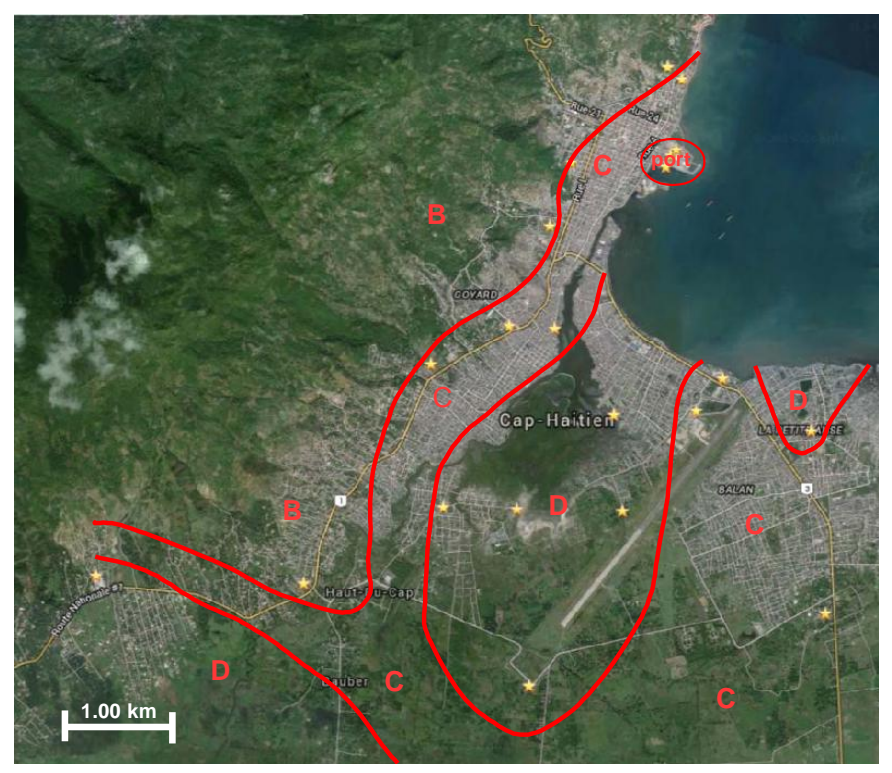

FIGURE 8

MAP OF SEISMIC SITE CLASS FOR CAP HAITIEN.

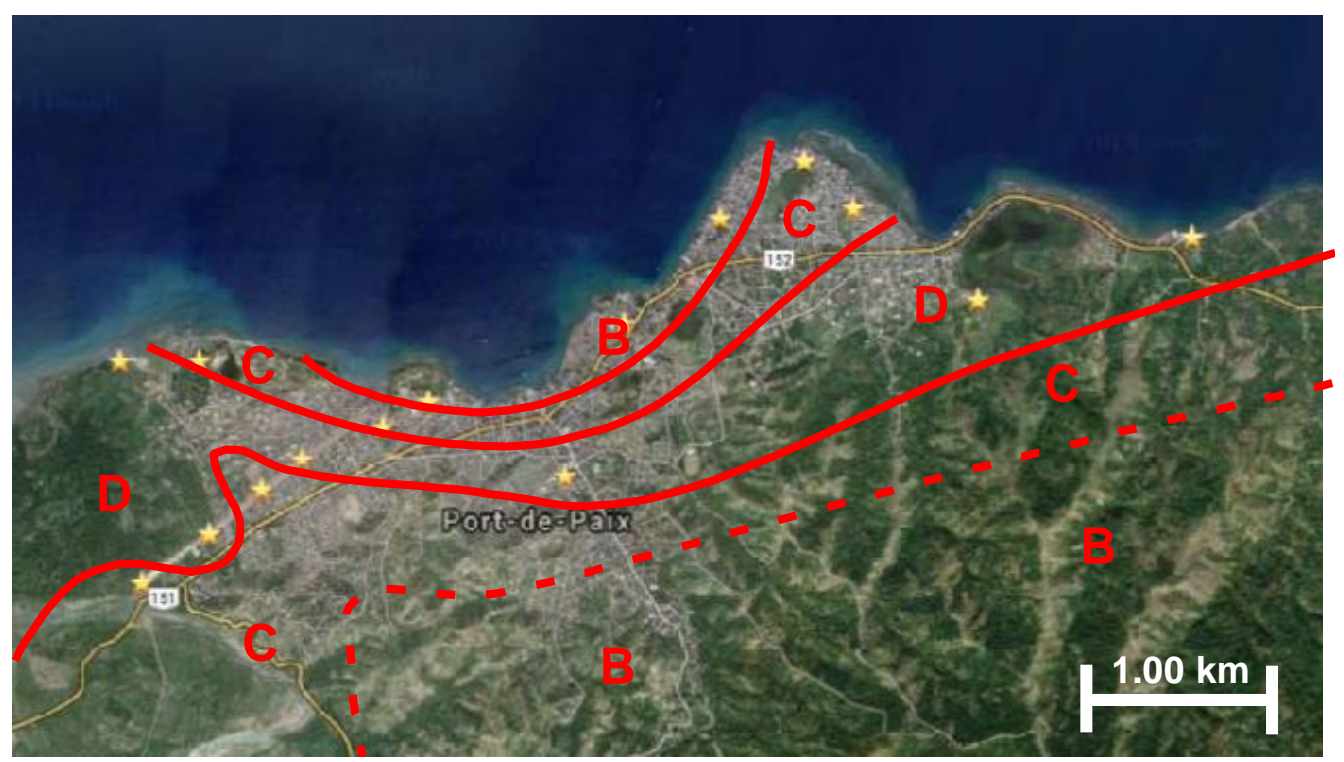

FIGURE 9

MAP OF SEISMIC SITE CLASS FOR PORT DE PAIX. 
International Journal for Service Learning in Engineering, Humanitarian Engineering and Social Entrepreneurship Vol. 10, No. 2, pp. 1-17, Fall 2015

ISSN 1555-9033

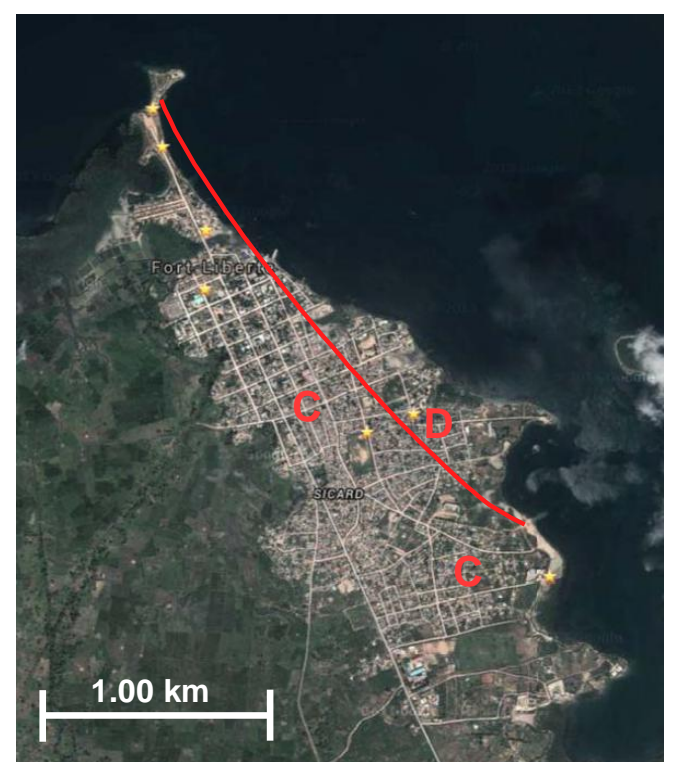

FIGURE 10

MAP OF SEISMIC SITE CLASS FOR FT. LIBERTE.

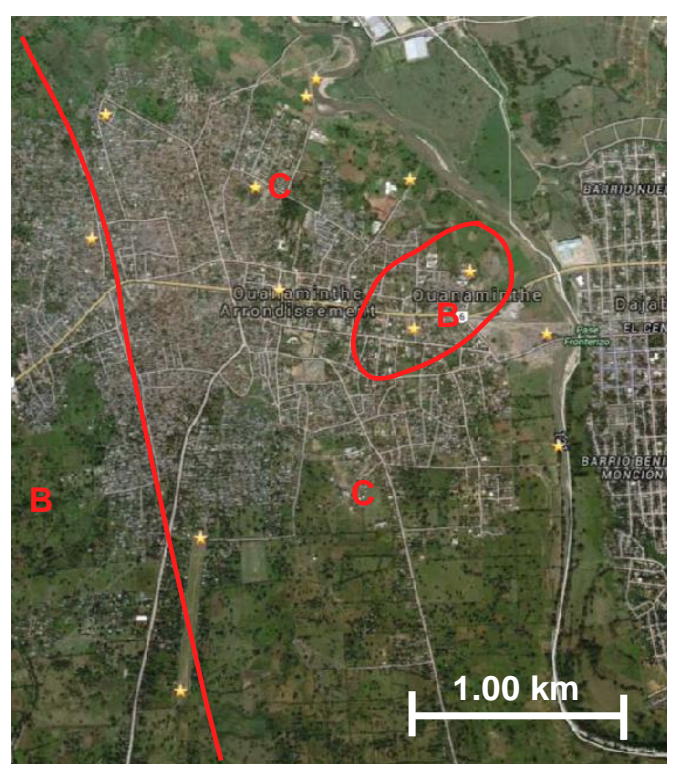

FIGURE 11

MAP OF SEISMIC SITE CLASS FOR OUANAMINTHE. 
International Journal for Service Learning in Engineering, Humanitarian Engineering and Social Entrepreneurship Vol. 10, No. 2, pp. 1-17, Fall 2015

ISSN 1555-9033

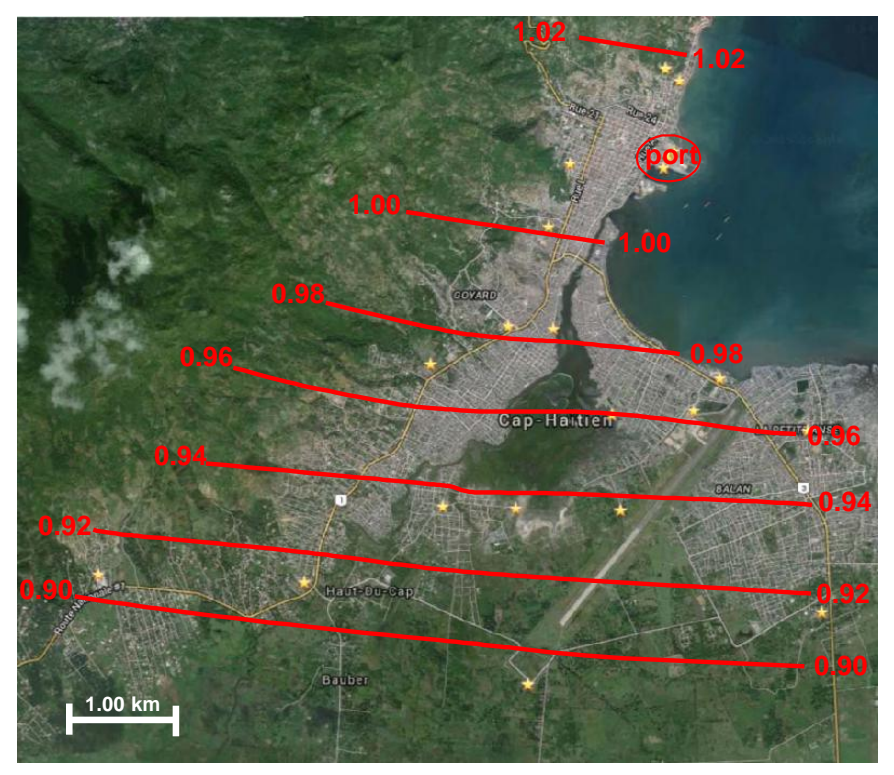

FIGURE 12

MAP OF SHORT-PERIOD SPECTRAL ACCELERATION $S_{D S}$ FOR CAP HAITIEN.

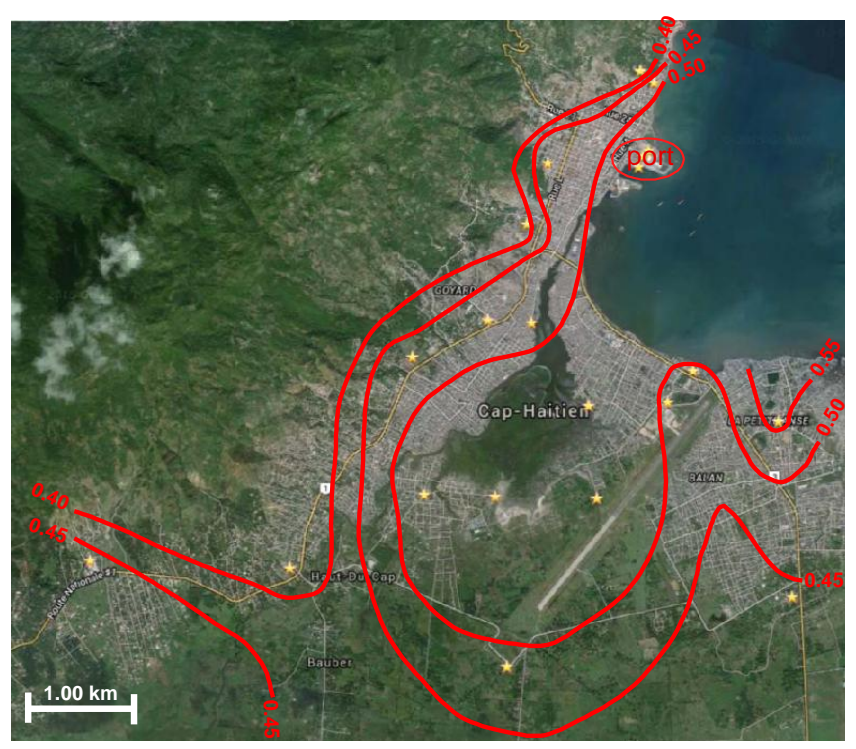

FIGURE 13

MAP OF LONG-PERIOD SPECTRAL ACCELERATION $S_{D I}$ FOR CAP HAITIEN. 
International Journal for Service Learning in Engineering, Humanitarian Engineering and Social Entrepreneurship Vol. 10, No. 2, pp. 1-17, Fall 2015

ISSN 1555-9033

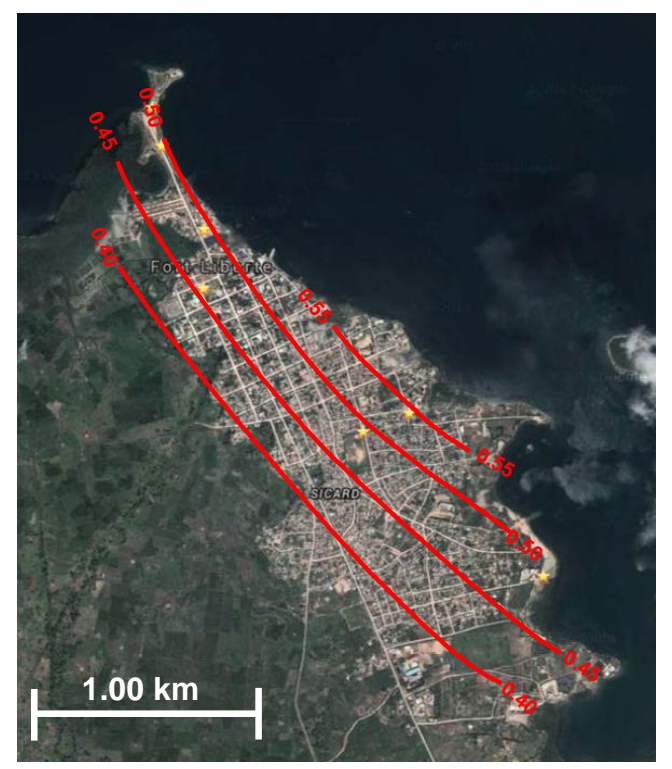

FIGURE 14

MAP OF LONG-PERIOD SPECTRAL ACCELERATION $S_{D 1}$ FOR FT. LIBERTE.

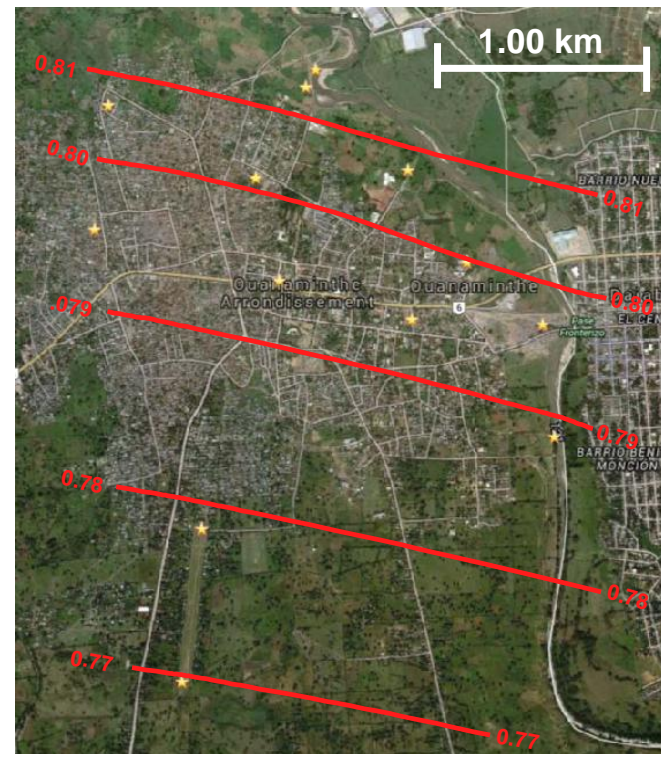

FIGURE 15

MAP OF SHORT-PERIOD SPECTRAL ACCELERATION $S_{D S}$ FOR OUANAMINTHE. 
International Journal for Service Learning in Engineering, Humanitarian Engineering and Social Entrepreneurship Vol. 10, No. 2, pp. 1-17, Fall 2015

ISSN 1555-9033

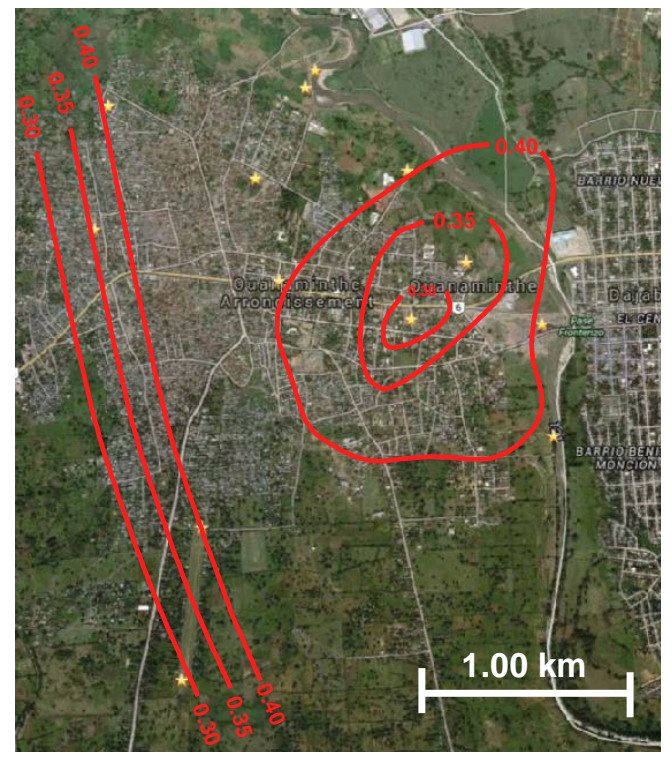

FIGURE 16

MAP OF LONG-PERIOD SPECTRAL ACCELERATION $S_{D I}$ FOR OUANAMINTHE.

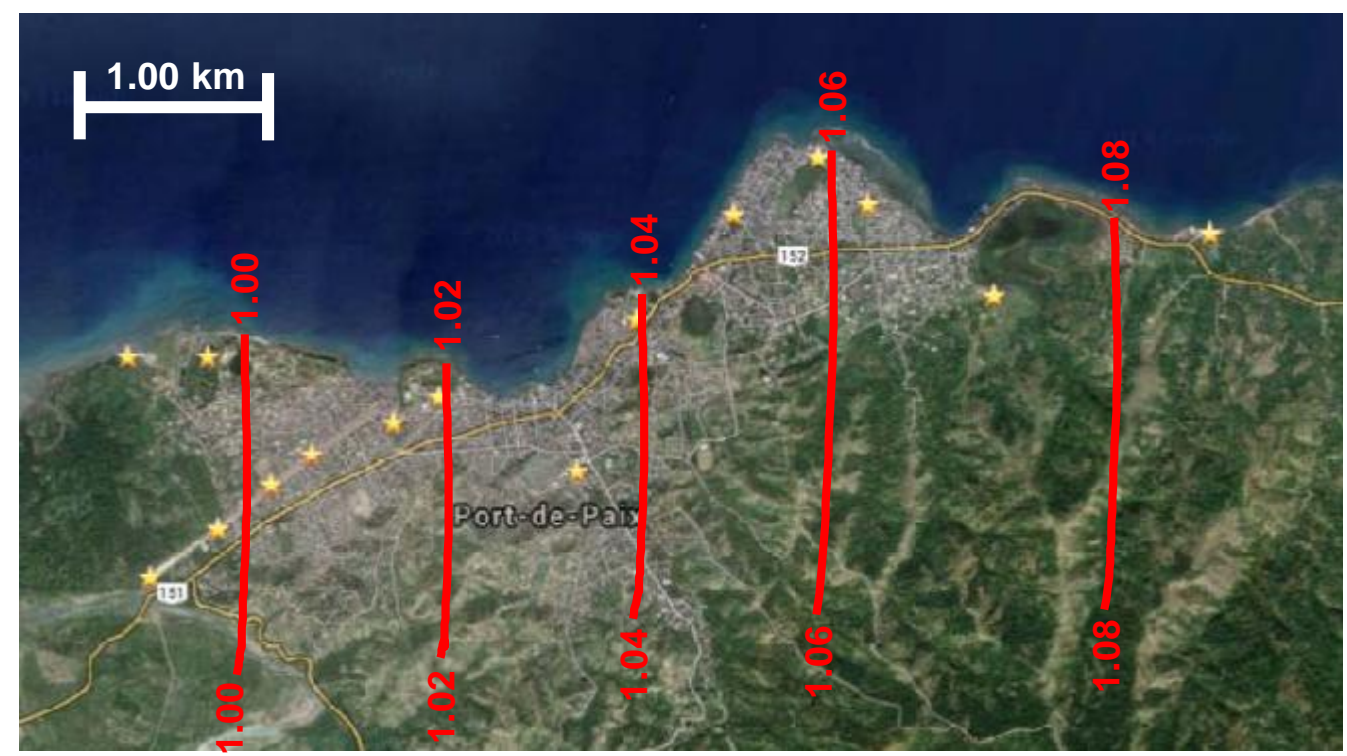

FIGURE 17

MAP OF SHORT-PERIOD SPECTRAL ACCELERATION $S_{D S}$ FOR PORT-DE-PAIX. 
International Journal for Service Learning in Engineering, Humanitarian Engineering and Social Entrepreneurship Vol. 10, No. 2, pp. 1-17, Fall 2015

ISSN 1555-9033

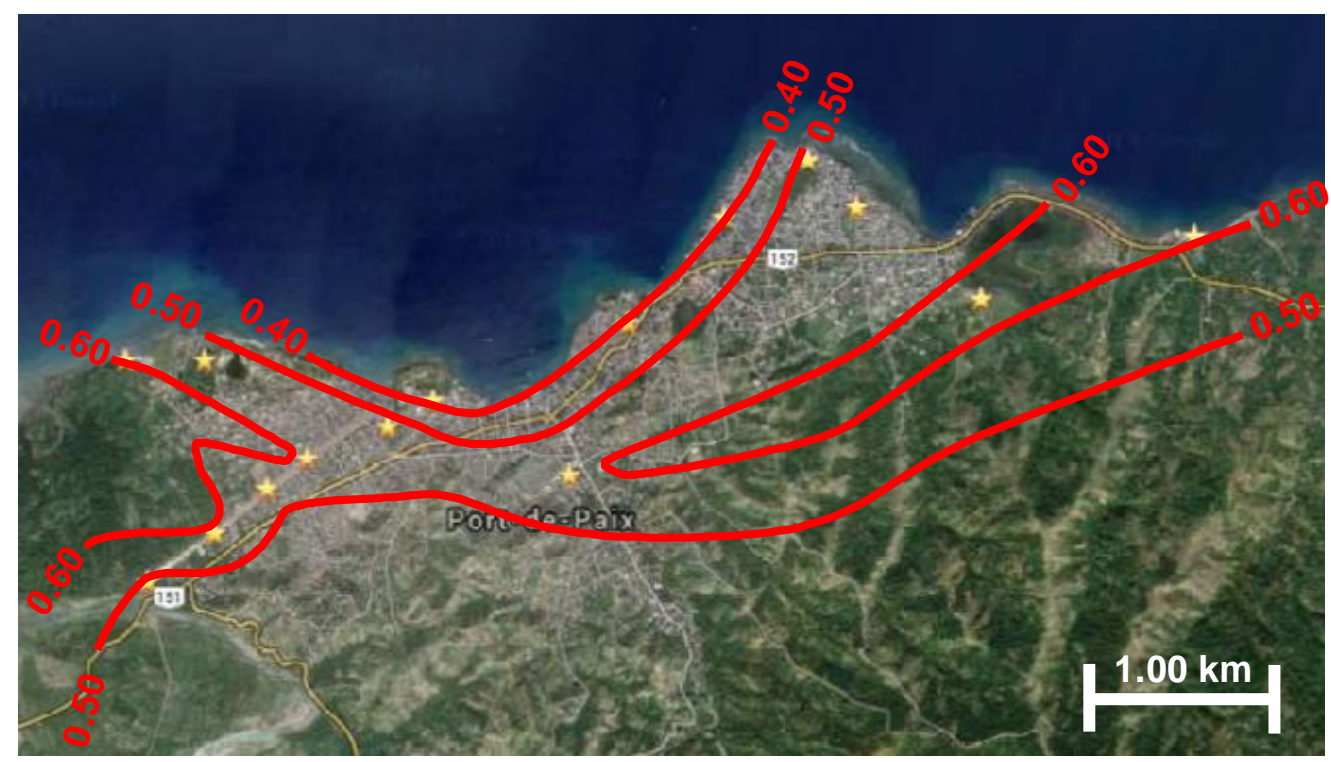

FIGURE 18

MAP OF LONG-PERIOD SPECTRAL ACCELERATION $S_{D I}$ FOR PORT-DE-PAIX. 